\title{
Humanitarian Action: A De Facto Durable Solution of Refugee Crisis?
}

\section{Sodip Roy ${ }^{1}$ and Hrithika Barua ${ }^{2}$}

\section{Abstract}

Humanitarian action tends to save lives of millions of forcibly displaced people around the globe during emergencies. In principle, it is temporary, but it continues for an extended period in the case of refugee crises. Among the three available durable solutions, the UN agencies can hardly implement them. Eventually, those solutions do not work in most of the twenty-first century refugee crisis. This study raises the question whether humanitarian action is likely to be another durable solution or not, and why it is preferred to other durable solutions to refugee crises. To that end, this study investigates the dynamics of ranges of solutions to protracted refugee situations (PRS) in different corners of the world. After an exploration of relevant secondary resources in qualitative setting, it concludes that statism causes many unavoidable politico-economic challenges to the traditional durable solutions while many self-devised comfort zones encourage the overuse of humanitarian action like a long-term solution to the problems. Addressing this incongruity of durable solutions to refugee crisis, the study urges that refugee regime reduce the dependency on humanitarian action and thus reinforce truly for alternative, less statist or transnational, and sustainable solutions.

Keywords: durable solutions, enforcement, refugee, temporary, transnational
${ }^{1}$ Corvinus University of Budapest, Hungary and Open School, Bangladesh Open University ${ }^{2} \mathrm{REACH}$ Initiative Bangladesh (Geneva based INGO), Cox's Bazar, Bangladesh

1s sodip.roy@gmail.com baruahrithika05@gmail.co $\underline{\mathrm{m}}$

(1) ${ }^{1}$ https://orcid.org/0000-00017257-5645

(iD) 2 https://orcid.org/0000-0002$\underline{8811-9780}$

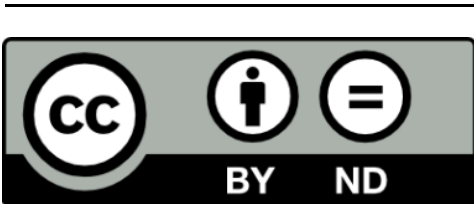

This article is published under the Creative Commons CC-BY-ND License (https://creativecommons.org/licenses/by-nd/4.0/). This license permits to use, distribute, and reproduce the contents of the publication for commercial and non-commercial purposes, provided that the original work is properly cited and is not changed anyway. 


\section{Original Article}

\section{INTRODUCTION}

Refugee crises and the number of refugees have reached an unprecedented high in the recent times. Currently, refugees constitute the highest number of forcibly displaced people, standing their number at 26.4 million in different corners of the world (UNHCR, 2021). And if that number is counted for a state, it will be the largest new country in the 21st century (Miliband, 2017). The extent of the refugee crisis can be well understood in the statement 'we live in the world of refugee' (Ager, 1999). In response to that gravity of the problem, the international refugee regime (IRR) led by UNHCR so far has devised three durable solutions: repatriation, local integration, and resettlement. However, there remain many root causes yet to be addressed; several researchers find that failure of enforcement of existing solutions is triggering many new refugee problems (Crisp, 2003) while a clear shift from durable solutions to humanitarian action to that end of refugee crisis is prevalent in the last couple of decades. Initially, refugee resettlement was preferable, and then it diverted to repatriation. However, now there is a mixed trend of local integration through humanitarian action. Refugee camps have got a permanent structure and transformed into a city in every protracted situation in exile (Martin, 2017). The UNHCR encounters a myriad of challenges in executing its mandate of three durable solutions. For example, it can hardly bring the host country, home country, or third country to a single table, or can manage funding for that. Consequently, refugees are caught up in humanitarian provision for year after year in refugee camps. The dilemma of solutions is fast replacing by humanitarian action for an extended period. However, key actors of international community (IC) play their part, sometimes minimum, even in case of humanitarian aid in refugee problem; they cannot materialize any of the durable solutions. There is no obligation for state parties to ratify 1951 Conventions as well as to approve durable solutions of refugee crisis so far. In these circumstances, policymakers, researchers, and practitioners in refugee crisis have been advocating for many alternative solutions. For example, Long (2009) argues for labour migration as the fourth durable solution while some refugee camps demonstrate for 'autonomy project' (Garicia, 2013) as a solution of human rights crisis permanently. However, few other alternatives have strong arguments in favor, but refugees are being grappled in humanitarian settings.

Henry Dunant was the key person for lobbying about the Geneva Convention in 1864 after the battle of Solferino in 1859. The Convention put the role of the International Committee of the Red Cross (ICRC) in ensuring respect during a war, and that lasted until the Second World War (WWII). It sought to combat widespread brutality and 


\section{Original Article}

human rights violations. To meet its promises, humanitarian action sometimes challenges Westphalia's policy of non-interference in the internal affairs of sovereign states and the humanitarian values of the ICRC. Since the mid-twentieth century, humanitarian action has been a dominant mechanism in framing global security, assistance, and democratization (Fielding, 1994). Theoretically, humanitarian action is operated according to several principles: universality, humanity, independence, neutrality, and impartiality but practices of humanitarian action have distinctions and contentions for politicization in the time being (Leader, 1998). Refugees belong to the constant focus of such humanitarian action for the protection of their lives. During this period the UNHCR received the UN universal mandate to protect refugees worldwide and end the refugee cycle. Although, it minimized refugee crisis in Europe until Cold War, refugee crisis is increasing exponentially in the global south beyond its capacity and needed to focus on ad hoc humanitarian action. It obliged the establishment of an institutional set up of the Department of Humanitarian Affairs which later was transformed into UN Office of the Coordination of Humanitarian Affairs (OCHA) (Billing, 2010). Thus, humanitarian action has an institutional and stronger mandate in assuaging refugee crisis to some extent.
Therefore, the study focuses on the growing dissonance of durable solutions and links this with much dependence on humanitarian action instead of reframing or minimizing the shortcomings of traditional solutions. This study neither denounces the importance of humanitarian action nor claims any policy for a solution but criticizes the current trend of solutions and looks into why and how traditional durable solutions are converging to humanitarian action. However, it does not purport a ground policy or theory; it is believed that the study will at least create a moral impetus for the IC and UN agencies against this transformation of undesirable solutions to refugee crisis. It is important to bring the current alarming trend of refugee solutions in the fore to prevent the forced migration in the coming days. If it is tempting to the IRR that humanitarian action is a well-fit solution to refugee crisis, there will be hardly any effort to end the genesis of forced displacements which will ultimately create more new crises and continue to expand the humanitarian industry further.

This article proceeds in five sections. The first section has highlighted an overview of the intensity of refugee crisis and the policy implications for durable solutions from international refugee agencies. The section that follows outlines the principles, mandate, and strategies of durable solutions and humanitarian action to set the forward scene of the study. It 


\section{Original Article}

also illustrates the dynamics of shifting of durable solutions in fixing or holding back the extent of refugee problem in different contexts. It sheds light on how and why the IRR have been diverting their standpoints to those durable solutions for the time being. The third section illuminates the study procedure which delineates the data sources and details about the data collection process in a qualitative setting of secondary sources. While the fourth section analyzes the issue of compatibility and incongruity between durable solutions and humanitarian assistance, and how the latter is taking over the space of durable solutions by framing many justifications in the dayto-day activities. And finally, it sums up and concludes that it is high time for policymakers, practitioners, and researchers to raise their voices against this de facto durable solution to refugee crisis. Therefore, the study believes that it may put moral pressure to the IRR at least $a$ bit to find out sustainable solution globally based on transnational engagement.

\section{LITERATURE REVIEW}

Article 1 of the UNHCR Convention in 1951 entailed two different durable solutions for refugee: repatriation, and assimilation as local integration and resettlement. To Black and Kosser (1999), durable solutions are those available initiatives for refugee, which can dissolve their suffering and need for international protection under humanitarian action. All these mechanisms are considered convincing to make an end to the plight of refugees and their need for international protection and reliance on humanitarian aid (Long, 2014). These solutions are persuasive in securing the rights of refugee entitled under refugee law and human rights law while security is a priority of refugee's rightsbased solutions. But in International Refugee Law, there is no legal authorization of durable solutions (Turk and Dowd, 2014). These are the choices of states, not intrinsic in nature and require collective commitment so that millions of displaced people can rebuild their lives. The IC ideally cannot be a beneficiary but a facilitator of the solution initiatives. Nevertheless, several actors eye on the gain from refugee politics instead of solution (Greenhill, 2010).

The challenges of durable solutions began particularly in the mid-1980s while the developed countries identified the flight as only for economic purpose, refugees are chaotic elements in their land and persistent volatile situation in the source countries, a highly costly burden for UNHCR (Gallagher, 1994). But refugee crisis desperately looks for a viable and sustainable solution (Bradley, 2019). The urgency is perceived by most of the actors who have recently come up with many new strategies such as the Global Compact for Refugee (GCR), New York Declaration (NYD). Prior to this, Responsibility to Protect (R2P) argued for humanitarian intervention to 


\section{Original Article}

prevent genocide, war crimes, ethnic cleansing, and crime against humanity.

\section{Refugee resettlement}

Three solutions were adopted as a pathway to the peaceful ending of refugee crisis. The most successful durable solutions were resettlement and local integration in the 1960/70s, the period which represents the supremacy of communism and colonialism (Long, 2014). Resettlement is defined as transferring refugees from a state in which they initially sought security to a third country that agreed to admit them with permanent residence status. Until the mid-1980s, resettlement was generally regarded by receiving states as the preferred durable solution of the problem. Most notably, resettlement was exercised to tackle the Vietnamese boat people crisis, which resulted in almost 2 million resettlements (Feller, 2001). But later, the resettlement particularly the political asylum was blocked as being overused and sometimes abused in Europe (Gallagher, 1994). Resettlement offers a permanent solution for refugees who are determined as the most vulnerable by the UNHCR. But only a limited number of refugees have had access to it ever since. By 2016, even at its latest high point, only 1 per cent of the global refugees were resettled (UNHCR, 2018). Key refugee receiving countries decrease the number of resettlement quotas gradually and the trend is plummeting worldwide. Moreover, the UNHCR and prospective receiving countries agreed to promote 'Strategic Use of Resettlement' with a view to achieving more local integration in the host countries (Van Selm, 2014). For example, during the Libyan refugee crisis, European ministers rejected the call for resettling Libyan refugees in EU instead they urged the UNHCR to try for other durable solutions elsewhere across the globe (Garlic and Selm, 2012). On the one hand, it may be seen as a symbol of extra-regional states' willingness to share responsibility, on the other, it may represent a disincentive to repatriation by encouraging some refugees to remain in the host state hoping to be resettled.

Currently, fewer than forty countries have a resettlement program, they accept skilled refugees who might be more helpful for their community in the camps too. But they do not support the labour migration from refugee that could minimize the problem to some extent globally and no considerable number of refugee labor accepted in the third country. Most of the time, the decision depends on the resettlement countries themselves. Furthermore, Action Plan for Developing countries in 1984, endorses the third country resettlement as the least desirable and costly solution of refugee crisis (Cuenod, 1989). Islamophobia and xenophobia have added anti-refugee sentiment very recently in the cases of resettlement in developed countries, particularly in Europe, the USA, and South Africa. Consequently, refugees are discouraged of asylum rights in 


\section{Original Article}

those countries and face deportation to the conflicting zones in humanitarian provision. The developed countries prefer to finance for humanitarian action somewhere near the source country of refugee (Franke, 2009). They come forward with the international legal framework and provide for more aid even to stop human smuggling and human trafficking into their territory (Anderson, 2014). The same understanding of refugee crisis calls for burden-sharing within a strategy of humanitarian action and development.

\section{Refugee repatriation}

Immediately after the WWII repatriation was not an option either of resettlement or integration. The ending of the cold war posed decisive challenges for resettlement, and repatriation gained much acceptance among the different refuge states. Two valid reasons- (1) people from poor countries started flight to rich countries to run away from poverty, democratization led to migration, and (2) growing association of refugees with migrants - turned wealthy nations back to offer resettlement. (Long, 2014). During the early 1990s, throughout Africa and Asia, it strengthened the idea that repatriation is the easiest and sometimes the only way to end refugee cycle. Sadako Ogata, the then UN High Commissioner for Refugees, proclaimed the 1990s as the decade of repatriation and more than ten million refugees returned to their countries such as in Afghanistan, Cambodia (Chimni, 1999).

A number of refugee populations for example Rohingya's in Bangladesh in 1992, Ethiopian's in Djibouti, and Cambodian's in Thailand were all subjected to forced repatriation in the 1970's and 1980's. Particularly, the repatriation of 200,000 Rohingya refugee in Burma in 1992-93 manifests the weakness of the most favorable durable solutions (War and Wong, 1997). They repeatedly have been persecuted by the Burman government and fled to Bangladesh in the largest influx of 700,000 in August 2017 than the number of previous flights in 1978, 1991. Rohingya refugees are now the most persecuted and vulnerable as well as stateless refugee in the world (Ahsan Ullah, 2016; Roy, 2020). The international refugee system could not ensure their safety and protection of human rights in the country of origin (Burma). It is assumed that once the repatriation occurred, the crisis is solved and no legal framework for follow-up is available internationally. But returnees must have to feel safe and secure after their return; at least they should not be afraid of losing their life in repetitive state-run persecution (Loescher and Milner, 2005). Considering their previous experience in Burma, the Rohingya people in Bangladesh have rejected the call for repatriation to Myanmar consecutively two times in 2018 and 2019 (Sakib, 2019). Similarly, a tripartite agreement among Kenya, Somalia, and the 


\section{Original Article}

UNHCR was signed in November 2013 to support return but by May 2016 only 5,200 refugees had repatriated in Somalia under its auspices. It is evident that most of the refugees in Dadaab of Kenya do not want to go back to Somalia voluntarily and may only do so under force. Some of the Somali refugees claimed after return in Somalia that they are the victim of betrayal of the UN aid workers in Kenya. They have been dragged in a warzone from the sanctuary in Dadaab, having no food, protection, security, health services but are facing terrorist attacks oftentimes in Mogadishu. Henceforth, refugees are entering the humanitarian setup in Kenya again (Hujale and McVeigh, 2017). The refugee camps are safer and livable than their return in the deadly country of origin wherever even the newly devised strategies such as R2P or NYD are not enforced to save their life in vulnerability. The same pace of protection and security is not active in Somalia. Putting differently, the UN refugee agency is more active in providing humanitarian assistance rather than focusing on the root causes of refugeehood. Thus, humanitarian action has turned into a key mechanism of avoiding the criticism of growing involuntary repatriation from the protracted refugee situation (PRS) as well.

\section{Local integration}

Local integration refers to the method for refugees to gain permanent residency or naturalization in their host country. The 1951 Convention has a mandate for local integration of refugees in the refuge, however, it depends on refugee's caseload and the host country's social and economic conditions (UNHCR, 2011). Groups that are frequently considered as priorities for local integration include refugees born on the territory of the host country who would otherwise be stateless, refugees who have no chance of repatriation soon, and refugees who have formed close ties to the host country (UNHCR, 2018). Currently, $80 \%$ of the refugees live in developing countries in the global south, which cannot bear the burden in the long run. Such host countries are not only poor but also undergo in the heavy transition of democracy within their fragile institutional setting. They are incessantly in sought of development and other policy aid from the global north and expect legitimacy of the incumbent regime (Saikal, 2006). This way the influx can be stopped in the refuge temporarily, but refugees have to spend their lives in de facto local integration in the refugee camps under humanitarian assistance for an unending period. It is also the choice of the refugees who grew up in exile as well as those who managed livelihoods in their host countries over many years. Although, host states are reluctant to expand public services and minimum human rights to refugees.

The case of Palestinian refugees is an explicit example of permanent humanitarian action without any 


\section{Original Article}

exception. Similarly, Somali refugees in Kenya, Burundian refugees in Tanzania, partially the Rohingya refugees in Bangladesh are few but are not the exhausted the list of long-term humanitarian operation for refugees worldwide. The ad hoc solution has become the permanent solution in those mutually inclusive humanitarian settings and local integration does not happen in the actual sense (Betts and Collier, 2017). This phase does not provide any guarantee of citizenship of the people caught up in humanitarian action, other than unofficial local integration. Moreover, humanitarian organizations become busy with new crises anywhere else, and the flow of assistance is likely to decrease gradually.

\section{METHODOLOGY}

The study is based on secondary data. Data has been collected from different studies on the largest ongoing refugee crisis around the globe for decades. The literature consulted here falls into two categories- the present dynamics of durable solutions to refugee conundrum, and the dependency on humanitarian action of international refugee regime. The literature includes but is not limited to academic journals, UNHCR reports, government reports, policies, and analysis of research organization and popular media on respective contexts. Tellingly, the literature examines critically on how the recent developments about durable solutions specifically local integration has been backing up under the humanitarian cover. In addition, it has explored and exemplified some policy implications and strategies to durable solutions particularly from the context of refugee crisis related to Somali refugees in Kenya, Burudian refugees in Tanzania, and Rohingya refugees in Bangladesh to substantiate the arguments, not ideally as case studies.

\section{FINDINGS AND DISCUSSION}

The future of state centric durable solutions

It is well researched that state-centric durable solutions of refugee crisis are no more effective today. And the arguments of this study that durable solutions are not happening frequently, not only because of their intrinsic problem of the tools but also because of the intention of the IC and the UN refugee agencies who are reluctant to bear the burden and admit their responsibility (Ahmad, 2017). It is evident that former colonies in the global south are generating the maximum number of refugees till today, firstly because of the colonial residue of racism then from their prescription of nation-state and liberal democracy (Anthony, 1991; Keely, 1996). It is doubtful whether the Global north wants to establish human rights, peace, and security worldwide, although primarily it is their responsibility to cooperate to that end (Gottwald, 2014). Ironically, they hardly focus on structural causes of 


\section{Original Article}

refugee crisis as well as proactive steps from UN agencies to stop physical causes on the ground (Ruaudel and Morrison-Metois, 2017). Consequently, most of the refugees from the global south spoil their lives in refugee camps under humanitarian assistance for more than twenty years on average (UNHCR, 2017). Some of the PRS are as follow-

\begin{tabular}{|c|c|c|c|}
\hline 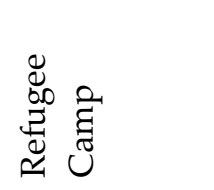 & 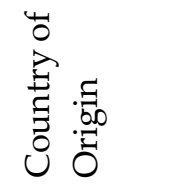 & 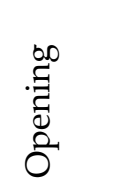 & 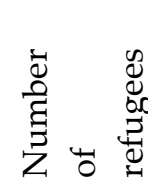 \\
\hline $\begin{array}{l}\text { Dadaab } \\
\text { refugee } \\
\text { complex, } \\
\text { Kenya }\end{array}$ & Somalia & 1991 & 218,873 \\
\hline $\begin{array}{l}\text { Kutupalong, } \\
\text { Cox's Bazar } \\
\text { Bangladesh }\end{array}$ & $\begin{array}{l}\text { Rohingya } \\
\text { refugee } \\
\text { from } \\
\text { Myanmar }\end{array}$ & $\begin{array}{l}1991- \\
92\end{array}$ & $\begin{array}{l}200,000 \\
(1 \\
\text { million } \\
\text { since } \\
2017)\end{array}$ \\
\hline $\begin{array}{l}\text { Camps in } \\
\text { Tanzania }\end{array}$ & $\begin{array}{l}\text { Burundi } \\
\text { and } \\
\text { Congolese }\end{array}$ & 1996 & 246,745 \\
\hline $\begin{array}{l}\text { Camps in } \\
\text { Uganda }\end{array}$ & $\begin{array}{l}\text { DRC and } \\
\text { Sudanese }\end{array}$ & $\begin{array}{l}\text { 1960s, } \\
1980 s\end{array}$ & $\begin{array}{l}1.4 \\
\text { million } \\
\text { (half in } \\
\text { prs) }\end{array}$ \\
\hline $\begin{array}{l}\text { Zaatari, } \\
\text { Jordan }\end{array}$ & $\begin{array}{l}\text { Syrian } \\
\text { refugee }\end{array}$ & 2012 & 80,000 \\
\hline $\begin{array}{l}\text { Camps in } \\
\text { Thailand }\end{array}$ & $\begin{array}{l}\text { Burmese } \\
\text { refugee }\end{array}$ & 1980 & 91,479 \\
\hline
\end{tabular}

Source: UNHCR, 2021.

Not only resettlement but also voluntary repatriation is costly while repatriation oftentimes does not sustain for a long time (Montenegro, 2016). UN refugee agencies have been encompassing their policy and legal framework such as UNHCR Protocol 1967, UN Executive Committee,
Responsibility to Protect (R2P) 2005, New York Declaration with the Global Compact on Refugee now and then, yet the millions of refugees are trapped in humanitarian assistance for decades. The principle of R2P offered hope against the repetitive exercise of humanitarian assistance (Khan and Ahmed, 2019). While the traditional durable solutions stopped at the border of sovereignty, R2P made at least the sufferer optimistic about acceptable solutions by addressing the issue of sovereignty in a different and effective manner. Khan and Ahmed (2019) further asserted that UN Security Council can even overcome the 'veto' issue sometimes with adequate evidence of persecution in saving the lives of refugee under R2P. Nevertheless, R2P fails because of quite the same reinforcing reasons and contested principles (Mamdani, 2010). Resultantly, the number of cases as well as the intensity of refugee crises keeps on the rise globally. Notwithstanding, the European refugee crisis in 20152016 obliges the UN refugee agencies for further commitments in the solutions of refugee crisis at large. Resultantly, the subsequent effort comes up with the NYD and its Global Compact on refugee to mitigate the crises. By acknowledging the inefficiency of the durable solutions, NYD was adopted as supplementary to those durable solutions (Hansen, 2018). The core of the NYD efforts advocates inclusion instead of integration and self-reliance. Since 2018, the IC and UN agencies have been emphasizing these 


\section{Original Article}

strategies under the cover of humanitarian provision with a flavour of 'refugee and development' in many African cases. However, there is a bit difference particularly to local integration since many host countries find it as the reinforcement of local integration and they rejected the chances of implementation of the Global Compact on refugee. Briefly, afterward the Action Plan in Developing Countries in 1984, a considerable number of strategies have been sorted out with over-emphasis on humanitarian provision with development (UNHCR, 2016) and have failed in mitigating refugee crisis so far. Those strategies are rightly applied to control the burst out of the camps but not to prevent and stop the genocide, crime against humanity. In other words, these strategies are strengthening the space and scope of humanitarian action instead of protecting the refugee. Policies, as well as commitments, are coming up from refugee agencies but enforcement of human rights laws here clashes with sovereignty and in the border of nationstate (Balibar, 2013; Roy, 2021). The consequences reflect the lack of both political and economic support of the IRR and the global north to refugee crisis (Bradley, 2019).

Humanitarian action: the last resort for refugee?

The above discussion explains that none of the durable solution individually or as an integrated whole is effective but putting the humanitarian action in the centre of refugee cycle which leads us to think that humanitarian action is the ultimate solution of refugee crisis. Every durable solution is now under question (Long, 2014). Here the question also arises about the period of the durability of these solutions that how long it sustains to those people- a decade, two decades, or a generation? Sometimes durability of durable solutions becomes more transient than humanitarian assistance in host countries and in the countries of resettlement without effective policies. It continues for decade after decade, refugees face their life and death in the refugee camp, which blurs the demarcation between durable solutions and humanitarian provision. While resettlement as a durable solution becomes the most elusive and refugees suffer from trauma and violations of human rights because of production of life-threatening xenophobia. The same consequences oftentimes occur also in the two other solutions: repatriation and local integration. Refugees live under humanitarian action even after their repatriation and in case of local integration in host countries (Stein, 1986). There are many arguments to the defender of humanitarian action, but the non-state-centric nature of humanitarian action is considered as the main grounds for its acceptability to IRR and IC than any other mechanism. It is the forcedly displaced people who take shelter anywhere in their geographical proximity, and later UN 


\section{Original Article}

refugee agency endorses the space as a camp under the humanitarian provision. Refugees themselves generate necessary political space for humanitarian action to continue even after the incapability and disagreement of the host country, but rarely undertake such activities in other side of the border or the country of origin. The humanitarian space, however, is inside the state but remains exceptional in practice (Agamben, 1998). Put differently, the UNHCR exercises international leverage to stop the displaced people anywhere nearby, obstructing their flights to developed countries (Barnett, 2014). Humanitarian industry exploits the power of refugee in the name of saving humanity and continues for decade after decade as like in designated durable solutions so far (Belloni, 2007). It becomes the most comfortable zone for them as well. The state remaking and refugee scholarship is fading away, now there is no new state likely to emerge and take back her people from exile. The discourse of nation-state accelerates the creation of many new nations within a state under the cover of liberal democracy and absolute sovereignty, in which many imagined communities engage in 'new war' (Kaldor, 2013) but cannot give birth of a new nation-state eventually. Thus, it continues to displace more people forcefully but cannot return them, even once the 'new war' ended. The UN refugee agency also cannot intervene in the intra-state issue because of the extent of sovereignty of the state
(Haddad, 2003). The autonomy project for forcibly displaced people remains elusive in present-day international politics. As a result, this tailor-made solution has repeatedly been applied across the globe and standing up as a de facto solution. In Africa, Kenya is the home to Somali and South Sudanese refugee camps. Besides, for Congolese, Rwandans, and Burundians, there are decades-old camps in Tanzania. Refugees can see their death in a precarious limbo, their rights for a durable solution is suppressed by everyday humanitarian activities. Scope and understanding of humanitarian action are in expansion, OCHA plans to cover up more people from the rural and urban area under its framework (Barnett, 2014). It is alarming that the same pace of effort is not visible in the case of the three durable solutions currently.

Though there is no better option during emergency, humanitarian action cannot be a solution because "there are no humanitarian solutions for humanitarian problems" (Sadako Ogata, cited in Reiff, 2002). Humanitarian action emphasizes the temporary solution rather than the original cause of the problem (Reiff, 2002; Terry, 2002). Although, it is effective in protecting Western states from the spillover effects of political crises in the world peripheries; they are reluctant in solving the problems that they pretend to contribute (Gottwald, 2014). It is one of the most contentious and defining features of post-cold war 


\section{Original Article}

politics. Humanitarianism perpetuates war and suffering. Instead of allowing a war to be fought to the bitter end, it defends the dignified idea that letting the stronger faction prevail to endorse the law of the jungle (Belloni, 2007). Critics of humanitarian action claim that the expectation that respect for human rights must be part of a peace settlement, political solutions cannot be justified in human rights terms. To be sure, humanitarianism is seen as an ethic as a political mode of territorial control and governance of international relations rather than a consensus and permanently established framework (Terry, 2002). It is crucial in saving lives, providing necessary medical care, and recording the plight of the people. But the way humanitarian aid is embedded in a particular society demonstrates a part in shaping power relationships between foreign and local actors. The dependency of South on North plays a role in this case too. Irregular migrants are used as weapon for material and diplomatic gain. Humanitarian power leads to categorize some people as migrants and some as experts which refers to the asymmetrical power relations between donor countries and developing countries (Pringle, Hunt and ten Have, 2015). In many contexts, humanitarian agencies are viewed as donor countries' military and political agendas rather than fixing refugee crises (Mills, 2005). Humanitarian aid enhances the influence of non-state actors over state actor indirectly by encouraging them to spend more directly on security through taxation, the transfer of humanitarian assets and market interactions between political elites and humanitarian agencies. The complexity of international relations is such that there is no existence of pure humanitarian work particularly in conflicting emergencies (McFarlane and Weiss, 2000). Besides these, the host country oftentimes loses control over the humanitarian space, which emerges many valid causes of securitization of the camps and 'new war'. Radicalization and growing agencies of the refugees also jeopardize and diminish the flow of aid, which in the long run causes starvation and death of many refugees without minimum health services. Therefore, the dependency on humanitarian action cannot save the intended lives, it can just keep waiting for the demise of those lives (Belloni, 2007). Tellingly, it sometimes obstructs the spirit for durable solutions (Vayrynen, 1999).

Evidently, the UNHCR lacks political mandate (Loescher and Milner, 2005) which ideally absorbs from the state party of the refugee Convention in 1951. But it could not convince many of countries because of the modalities of solutions of refugee crisis back in 1950s which was much Europe centric (Oberi, 2001). It should amend and upgrade many clauses with more enforcement power and clear-cut responsibilities of the state parties particularly in countries of origin. The UNHCR seems inactive on fixing the issue of 'Asian rejection' of UN Refugee Convention. 


\section{Original Article}

Since many countries do not ratify the convention and accept refugees at large, humanitarian action turns into a de facto solution. But the burden goes very unevenly to few host countries. Currently only five countries host 39\% of the world refugee (UNHCR, 2021). Among them, a considerable number of refugees from Germany have been distributed among the EU countries as per its refugee and asylum policies. Such transnational model or distribution of refugees can be a way out for displaced people in some other regional countries around the globe (Van Hear, 2014). The Organization of African Unity Convention 1969 demonstrated well in minimizing and settling many refugees among them. The Cartagena Declaration of 1984 is another regional instrument of handling refugee crisis among the Latin American countries. Where the other regional blocks cannot come up with any of their refugee policies, UN organizations and the IC can play the lead role in funding and guidance to those countries to that end. For instance, the Association for Southeast Asian Nations (ASEAN) is ignoring the Burmese refugee crisis (Pudjibudojo, 2019). All-out cooperation among the ASEAN countries can solve the problem effectively. Eventually, distribution of refugee among the regional countries is easier than resettlement in third countries. But strong effort is required for this shift from state-centric solution to transnational solution regionally. Unending political conflicts and natural disaster often hampers the implementation of such transnational initiatives.

\section{CONCLUSION}

The number of refugee and the coverage of durable solutions are in a mutually exclusive relationship. Durable solutions are alarmingly failed and unsustainable in many cases of twenty-first century refugee crises. Many disconnected approaches have been devised frequently to invigorate those solutions but there are no changes in the nature of the outcome. Refugees are ended up in the camps to keep alive the humanitarian industry. They receive support from the same key actors of refugee regime, and the humanitarian program continues decade after decade. It becomes even more durable at least in longevity compared to traditional durable solutions. However, it is the responsibility of the UN agencies to ensure refugees' safety and protection in the place of origin or in a third country; they remain almost silent in the hour of need and take no stern action against even the perpetrator if any or the source country. Besides these, UNHCR raises the issue of low funding from the global north in implementing many planned repatriations that indirectly encourages humanitarian assistance in the host country (Betts, 2011). Thus, those who could play a stronger part in resolving the problems, only take part in financial contribution to that venture but that 


\section{Original Article}

ultimately cannot bring forth any good for the victims. However geographical location and strict immigration can apparently keep the gravity of the crisis away from, it is doubtful whether overlooking and demonstrating incapability to refugee crisis in global south can retain peace and security in the global north in future. Apart from that, if it is perceived by the West that some of the mechanisms of durable solutions are not only overused but also exhausted, then they must have to consider that humanitarian actions already have become highly abused and apolitical in practice.

Therefore, it has been highlighted here that it is high time to reduce dependency on humanitarian solution of refugee crisis, instead it can reinforce at least traditional durable solutions evenly and create impetus for alternative solutions. In this regard, the IRR must undergo substantive reformation of existing legal frameworks with a special focus on enforcement of the international human rights laws. Furthermore, there should be an obligatory provision for the source country to bear the burden of her people in exile until their timely return. Transnational solutions such as regional distribution of refugee, regional citizenship, building formal diaspora in the host or in a third country should also receive $\mathrm{UN}$ support. Besides, some scholars also argue for legitimization of refugee mobility to end the intensity of the crisis. In addition, post-national discourse may be in consideration to shift their nation-state centric solution of refugee crisis through regional entity-based joint integration program that has been happening in many cases of refugee crises in the world.

\section{Acknowledgement}

The publication is the outcome of the project "From Talent to Young Researcher project aimed at activities supporting the research career model in higher education", identifier EFOP3.6.3-VEKOP-16-2017-00007 COsupported by the European Union, Hungary, and the European Social Fund.

\section{References}

Agamben, G. (1998). Homo Sacer: Sovereign Power and Bare Life. Stanford university Press.

Ager, A. (1999). Refugees: Perspectives on the experience of forced migration. Pinter Pub Limited.

Ahmad, W. (2017). The Fate of Durable Solutions in Protracted Refugee Situations: The Odyssey of Afghan Refugees in Pakistan. Seattle Journal for Social Justice, 15(3), 591-661.

Ahsan Ullah, A.K.M. (2016). Rohingya Crisis in Myanmar: Seeking Justice for the "Stateless". Journal of Contemporary Criminal Justice, 32(3), 285-301.

Anderson, B. (2014). Trafficking. In E. Fiddian-Qasmiyeh, G. Loescher, K. Long \& N. Sigona (Eds.), The Oxford handbook of refugee and forced migration studies (pp. 355-368). Oxford University Press. 


\section{Original Article}

Anthony, C. G. (1991). Africa's refugee crisis: state building in historical perspective. International Migration Review, 25(3), 574-591.

Balibar, E. (2013). Masses, classes, ideas: studies on politics and philosophy before and after Marx. Routledge.

Barnett, M. (2014). Refugees and humanitarianism. In E. FiddianQasmiyeh, G. Loescher, K. Long \& N. Sigona (Eds.), The Oxford handbook of refugee and forced migration studies (pp. 241-252). Oxford University Press.

Belloni, R. (2007). The trouble with humanitarianism. Review of International Studies, 33(3), 451-474.

Betts, A. (2011). Protection by persuasion: International cooperation in the refugee regime. Cornell University Press.

Betts, A. and Collier, P. (2017). Refuge: Rethinking refugee policy in a changing world. Oxford University Press.

Billing, A. (2010). Humanitarian Assistance An Introduction to Humanitarian Assistance and The Policy for Sweden's Humanitarian Aid. Perspectives. 17.

Black, R. \& Koser, K. (1999). The end of the refugee cycle?' In R. Black \& K. Koser (Eds.), The end of the refugee cycle? Refugee repatriation and reconstruction (1 $1^{\text {st }}$ ed.). Berghahn Books.

Bradley, M. (2019). Resolving Refugee Situations: Seeking Solutions Worthy of the Name. World Refugee Council, 9. https://www.cigionline.org/sites/defa ult/files/documents/WRC\%20Researc h\%20Paper\%20No.9web_1.pdf.

Cuenod, J. (1989) Refugees: Development or Relief? In G. Loescher \& L. Monahan (Eds.), Refugees and International Relations (1st ed., pp. 219-254). Oxford University Press.
Chimni, B.S. (1999). From resettlement to involuntary repatriation: towards a critical history of durable solutions to refugee problems. Centre for Documentation and Research, United Nations High Commissioner for Refugees. https://www.unhcr.org/research/work ing/3ae6a0c50/resettlementinvoluntary-repatriation-towardscritical-history-durable.html.

Crisp, J. (2003). No Solutions in Sight? The Problem of Protracted Refugee Situations in Africa: New Issues in Refugee Research. Working Paper No. 75. UNHCR, Geneva.

Feller, E. (2001). International refugee protection 50 years on: The protection challenges of the past, present and future. International Review of the Red Cross, 83(843), 581-606.

Fielding, L. E. (1994). Taking the next step in the development of new human rights: The emerging right of humanitarian assistance to restore democracy. Duke J. Comp. \& Int'l L. 5: 329-377.

Franke, M. F. (2009). Political exclusion of refugees in the ethics of international relations. In Hayden, P. (Eds.), The Ashgate Research Companion to Ethics and International Relations (pp. 309-328). University of St. Andrew, UK.

Gallagher, D. (1994). Durable solutions in a new political era. Journal of International Affairs, 47(2), 429-450.

Garicia, B. L. (2013). Resolving Regional Conflicts: The Western Sahara and the Quest for a Durable Solution. https://www.wilsoncenter.org/event/r esolving-regional-conflicts-thewestern-sahara-and-the-quest-fordurable-solution.

Garlick, M. \& van Selm, J. (2012). From commitment to practice: the EU response. Forced Migration Review, 39, 20. 


\section{Original Article}

Gorlick, B (2019). The Rohingya Refugee Crisis: Rethinking Solutions and Accountability. Refugee Studies Centre, Oxford Department of International Development, Working Series Number 131, 6-10.

Gottwald, M. (2014). Burden sharing and refugee protection. In E. FiddianQasmiyeh, G. Loescher, K. Long \& N. Sigona (Eds.), The Oxford handbook of refugee and forced migration studies (pp. 525-540). Oxford University Press.

Greenhill, K. M. (2010). Weapons of mass migration: Forced displacement, coercion, and foreign policy. Cornell University Press.

Grundy-Warr, C. \& Wong, E. (1997). Sanctuary under a plastic sheet-the unresolved problem of Rohingya refugees. IBRU Boundary and Security Bulletin, 5(3), 79-91.

Haddad, E. (2003). The refugee: The individual between sovereigns. Global Society, 17(3), 297-322.

Hansen, R. (2018). The comprehensive refugee response framework: A commentary. Journal of Refugee Studies, 31(2), 131-151.

Hujale, M \& McVeigh, K. (2017, 22 June). I feel betrayed: the Somali refugee sent from safety into a war zone. The Guardian.

https://www.theguardian.com/globaldevelopment/2017/jun/22/betrayedsomali-refugees-kenya-dadaab-campsent-from-safety-into-war-zone.

Kaldor, M. (2013). New and old wars: Organised violence in a global era. John Wiley \& Sons.

Keely, C. B. (1996). How nation-states create and respond to refugee flows. International Migration Review, 30(4), 1046-1066.

Khan, M. T. \& Ahmed, S. (2019). Dealing with the Rohingya crisis: The relevance of the general assembly and R2P. Asian Journal of Comparative Politic, 5(2), 121143.

Leader, N. (1998). Proliferating principles, or how to sup with the devil without getting eaten. The International Journal of Human Rights, 2(4), 1-27.

Loescher, G. \& Milner, J. (2005). Towards solutions for protracted refugee situations. The Adelphi Papers, 45(375), 67-84.

Long, K. (2009). Extending protection?: Labour migration and durable solutions for refugees. New issues in refugee research. 176. UNHCR.

Long, K. (2011). Permanent crises? Unlocking the protracted displacement of refugees and internally displaced persons. Refugee Studies Centre. Oxford Department of International Development. 8-20

Long, K. (2014). Rethinking 'durable' solutions. E. Fiddian-Qasmiyeh, G. Loescher, K. Long \& N. Sigona (Eds.), The Oxford handbook of refugee and forced migration studies (pp. 475-487). Oxford University Press.

MacFarlane, S. N. \& Weiss, T. (2000). Political interest and humanitarian action. Security Studies, 10(1), 112-142.

Mamdani, M. (2010). Responsibility to protect or right to punish?. Journal of Intervention and Statebuilding, 4(1), 5367.

Martín, C. G. (2017). Rethinking the concept of a "durable solution": Sahrawi refugee camps four decades on. Ethics E International Affairs, 31(1), 31-45.

Miliband, D. (2017). The Global Refugee Crisis and What To Do About It. James Martin Memorial Lecture. International Rescue Committee. https://www.oxfordmartin.ox.ac.uk/event/ 2388. 


\section{Original Article}

Mills, K. (2005). Neo-humanitarianism: the role of international humanitarian norms and organizations in contemporary conflict. Global Governance, 11, 161.

Milner, J. (2014). Protracted refugee situations. E. Fiddian-Qasmiyeh, G. Loescher, K. Long \& N. Sigona (Eds.), The Oxford handbook of refugee and forced migration studies (pp. 151-162). Oxford University Press.

Montenegro, C. (2016). Social protection: a fourth durable solution?. Forced Migration Review, 51, 62.

Oberoi, P. (2001). South Asia and the creation of the international refugee regime. Refuge: Canada's Journal on Refugees, 19(5), 36-45.

Pringle J. \& Hunt M. (2016) Humanitarian Action. In: ten Have H. (Eds.) Encyclopedia of Global Bioethics. Springer, Cham. https://doi.org/10.1007/978-3-31909483-0_235

Pudjibudojo, W. P. (2019). Criticizing the Handling of Rohingya Refugees in Southeast Asia by ASEAN and Its Members. Politika: Jurnal Ilmu Politik, 10(2), 229-238.

Reiff, D. (2002). A Bed for the Night: Humanitarianism in Crisis, Vintage, London.

Roy, S. (2021). The stateless Rohingya refugee: A critical analysis of nationstates of Myanmar and Bangladesh. Kasetsart Journal of Social Sciences, 42(3), 668-673.

Roy, S. (2020). Statelessness of Myanmar's Rohingya Ethnic Population: Assessing the Role of The International Community. Social Science Review, 37(1), 277-294.

Ruaudel, H. \& Morrison-Métois, S. (2017). Responding to Refugee Crises in Developing Countries: What Can We
Learn From Evaluations?. OECD. https://www.oecd.org/dac/evaluation/ responding $\% 20$ to $\% 20$ refugee $\% 20$ crisis $\% 20$ booklet.pdf.

Saikal, A. (2006). Afghanistan's transition: isaf's stabilisation role?. Third World Quarterly, 27(03), 525-534.

Stein, B.N. (1986). Durable Solutions for Developing Country Refugees. The International

Migration Review, 20(2), 264-282.

Terry, F. (2002). Condemned to Repeat? The Paradox of Humanitarian Action, London: Cornell University Press.

Türk, V. and Dowd, R. (2014). Protection gaps. In E. Fiddian-Qasmiyeh, G. Loescher, K. Long \& N. Sigona (Eds.), The Oxford handbook of refugee and forced migration studies (pp. 278-289). Oxford University Press.

UNHCR (2011). Refugee Protection and Mixed Migration: The 10-Point Plan in action. https://www.unhcr.org/the-10-pointplan-in-action.html.

UNHCR (2016). New York Declaration for Refugees and Migrants. https://www.un.org/en/development/ desa/population/migration/generalass embly/docs/globalcompact/A_RES_71 _1.pdf $>$.

UNHCR (2017). Global Trends: Forced Displacement in 2016. UNHCR. www.unhcr.org/5943e8a34.pdf.

UNHCR (2018). Towards a global compact on refugees.

http://www.unhcr.org/towards-aglobal-compact-on-refugees.html.

UNHCR (2021). Refugee Statistics: Global trends at a glance. https://www.unrefugees.org/refugeefacts/statistics/.

Van Selm, J. (2014). Refugee resettlement. In E. Fiddian-Qasmiyeh, G. Loescher, K. Long \& N. Sigona (Eds.), The Oxford handbook of refugee and forced migration 


\section{Original Article}

studies (pp. 512-524). Oxford University Press.

Van Hear, N. (2014). Refugees, Diasporas and Transnationalism. In E. FiddianQasmiyeh, G. Loescher, K. Long \& N. Sigona (Eds.), The Oxford handbook of refugee and forced migration studies (pp. 176-187). Oxford University Press.

Väyrynen, R. (1999). More questions than answers: dilemmas of humanitarian action. Peace

$\mathcal{E}$ Change, 24(2), 172-196. 